\title{
Lesson Study for Developing the Pedagogical Competence of Pre-Service Teachers by Integrating Character Values in Thematic Teaching at Elementary Schools
}

\author{
Komang Sujendra Diputra ${ }^{1}$, I Gusti Ngurah Japa ${ }^{2}$, I Made Suarjana ${ }^{3}$, Kadek Yudiana ${ }^{4}$ \\ \{komangsujendra.diputra@undiksha.ac.id ${ }^{1}$, igustingurah.japa@undiksha.ac.id ${ }^{2}$, \\ imade.suarjana@undiksha.ac.id ${ }^{3}$,kadek.yudiana@undiksha.ac.id $\left.{ }^{4}\right\}$ \\ 1,2,3,4 Universitas Pendidikan Ganesha, Indonesia
}

\begin{abstract}
This study aimed at developing students' pedagogic competence that consists of the ability to design the 2013 Curriculum thematic teaching integrated with character values through a lesson study. This study belongs to action research with an action of lesson study that was done in 2 cycles. The subjects were the students who took the practice teaching program and the object was the students' pedagogic competence in integrating character values with thematic teaching. The results of the study indicate that lesson study is able to improve the ability of students to design and implement integrated learning character values. The results of the effectiveness test show that lesson study proved to be effective in improving the pedagogical abilities of students integrating character values in thematic learning.
\end{abstract}

Keywords: Character, Lesson Study, Pedagogic.

\section{Introduction}

Character education becomes a priority issue in almost all countries in the world, including Indonesia. Various conditions found in recent years indicate the degradation of values and morality. This is increasingly more serious in the context of education. There are many social problems such as pornography among teenagers and even among children, gang fighting among students that has caused injuries, and plagiarism among students even in doctoral degree programs.

Character education is not new in education. It is a process of development of good character values in the students and aims at developing the ability of all people at school to make decisions, to give good examples, to maintain the good things and actualize them in daily life earnestly. Hence, character education is not only teaching to differentiate the good from the bad. [1] stresses three aspects of a good character: it has to involve moral knowledge, moral feeling and moral action so that it develops integrity of behavior and attitude in the students.

The government makes character building as one of the priority programs of the national development. Act No. 20 of 2003 states that formal education in Indonesia has to be able to balance the development of intellectual (academic) abilities. School is the best place for students to develop their characters, especially at the elementary school and junior high school levels. This is because the introduction of moral and character concepts is easier at these levels of education [2]. School functions as the best place for the students to practice doing good things by staying and interacting at the school [3].

The government has taken action concerning this character education by making the 2013 Curriculum effective, with its main characteristic being the implementation of integrative thematic teaching at elementary school. Integrative thematic teaching is one of the models of integrated teaching that uses themes to relate some subjects so that it can give a meaningful experience to the students [3]. Philosophically, the integrative thematic teaching uses a multidisciplinary approach, which means that the contents of teaching are taught in one unit. This approach provides opportunities to develop characters in all contents of teaching in such 
a way that the elementary school graduates will have abilities that cover attitude, skill, and knowledge.

Related to the implementation of character education at school, the process of character building has been left all this time to teachers who teach religion, civics, and guidance and counseling [2]. Ideally, character education is the responsibility of all teachers and this can be done by integrating character values into each area of teaching. The government clearly expects that all of the teachers have to choose characters that fit well with the basic competencies taught [6]. However, in reality, teachers still hesitate to incorporate character values into their lesson plans. This is caused by the fact that there is no guideline or standard on how to integrate character values into a lesson. In their study, [2] found that generally, elementary school teachers have implemented character education in their teaching, but this has not yet been integrated well in the teaching materials used. Hence, the implementation of character education in the teaching process has not been materialized. Based on the identification done by [7] in relation to the integration of character values into the 2013 Curriculum thematic teaching at elementary school, it was found that the teachers already know the 8 characters that can be developed in teaching, but they do not understand the detailed description of each character. They have selected and stated the character values that will be developed in the teaching but it is not clear how the character values and the activities or the steps are integrated into teaching. In this case, there is an impression that the character values that are stated in the teaching process are just "a display".

Starting from this finding and the result of identification above, The Department of Elementary School Teachers Education as the department with the mission of training the students to become professional elementary school teachers ought to respond seriously to the problem related to the implementation of character education at elementary school level. The students need to be trained to integrate character education into thematic teaching which is now made effective by the government. One of the forms of appropriate innovations is lesson study. This is in accordance with the result of the study done by Japa and Diputra (2016) which showed that lesson study can improve the competence of teachers in integrating character education which has a direct impact on the quality of character values shown by the students during the lesson.

Lesson study is the model of professional development by studying a lesson collaboratively and sustainably based on the principles of collegiality and mutual learning to develop a learning community. Lesson study is a process of correction and development of the teacher's knowledge in improving the quality of the lesson at the elementary school in Japan [4]. The core of lesson study is the occurrence of collaborative processes among all parties (teachers, stakeholders, and experts) in studying the lesson starting from the planning stage up to the reflection stage in order to improve the quality of the lesson.

state that lesson study has proven effective in improving teachers' pedagogic competence in teaching. In their study results, [1] [2] found that lesson study is able to improve the teacher's ability in preparing the lesson and implementing it in each cycle. This finding was supported [5] who stated that lesson study is able to help in improving the teacher's knowledge and the quality of the teaching in his or her field. However, there is no study on how to specifically develop teacher competency starting when they begin education as prospective teachers.

Based on the above explanation about its various advantages, lesson study will be effective in developing pedagogic competencies, especially for prospective teachers in primary school teacher education. Therefore, the effectiveness of lesson study in developing pedagogical skills PGSD students design needs to be empirically proven and character education integrated learning in the practice of real learning needs to be implemented. This needs to be done as an initial step to prepare prospective professional teachers who have the skills and abilities to integrate character values in learning in elementary schools. 


\section{Research Method}

This study aimed at developing students' pedagogic competence in integrating character values into thematic teaching through lesson study. Hence, this study was an action research with the adaptation of the One - Shot Case Study research design. The action was in the form of lesson study consisting of three states: 1) plan, 2) do, and 3) see, depicted in the following scheme.

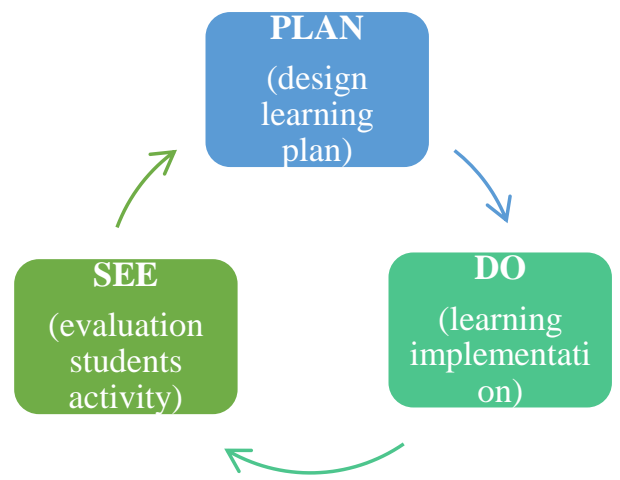

Fig. 1. Lesson Study Stage

The three stages formed a sustainable cycle that was adjusted to the condition after the "see" (reflection) stage, which means one cycle of action consisted of the three stages above. In this research, lesson study was conducted in 2 cycles.

In the "plan" stage, the group formation is carried out and then a plan for implementing learning is compiled together. Furthermore, in the "do" stage, the teacher models carry out learning in a predetermined class, while students and teachers act as observers of the learning process using the research instruments that have been developed. Finally, at the "see" stage, a postclass discussion or reflection activity is carried out. Reflections are followed by all group members who review the results of observations of each lecturer and the results of recording the learning process

The subjects of this study were 12 PGSD students in the seventh semester who were taking practice teaching programs that were done at 2 schools, namely at SD N 2 Liligundi and SD N 5 Banyuasri. The choice of school based on the location of the school was based on the fact that one school is located in the city and one school is located in the suburbs. This study also involved 12 teachers who guided each student who was the subject of the research and, at the same time, acted as observers at the time of the "do" stage. The object of study was the students' pedagogic competence that consists of two dimensions, namely, 1) the ability to design a character value integrated thematic lesson and 2) the ability to implement a character value integrated thematic lesson. The data on the students' ability to design a character value integrated thematic lesson were obtained from the scores in the lesson plan written by the students, while the data on the students' ability to implement a character value integrated thematic lesson were obtained from the students' scores in their teaching ability. The data were collected using an instrument developed by the researchers that were based on the items in Teacher's Competence Evaluation, which was reviewed by 2 experts in education evaluation. The data were then analyzed using the quantitative descriptive analysis. The formula used calculates the average score of each respondent as follows.

$$
\text { Mean Score }=\frac{\sum \text { score }}{\text { SMI }} \times 100 \%
$$

The guidelines used to provide assessment and decision making are presented in the following Table 1. 
Table 1. Conversion Guidelines Level of Achievement with Scale 5

\begin{tabular}{cc}
\hline Achievement Level & Qualification \\
\hline $90-100$ & Very good \\
\hline $80-89$ & Well \\
\hline $65-79$ & Enough \\
\hline $55-64$ & Less \\
\hline $0-54$ & Very less \\
\hline
\end{tabular}

Furthermore, to calculate the level of significance of the difference in the ability score to design and implement integrated thematic learning character values between the two cycles, inferential statistical analysis sign test is used with a significance level of 5\%. The hypotheses tested are:

First hypothesis:

$\mathrm{H} 0$ : there is no difference in the ability of students to design integrated thematic learning character values.

Second hypothesis:

H0: there is no difference in the ability of students to implement integrated thematic learning character values.

If there are significant differences, followed by testing the effectiveness of using the gain-score formula from Meltzer (2002) with criteria:

Table 2. Gain-Score Criteria

\begin{tabular}{cc}
\hline Gain-Score & Quality \\
\hline $\mathrm{g}>0,7$ & High \\
\hline $0,3<\mathrm{g} \leq 0,7$ & Medium \\
\hline $\mathrm{g} \leq 0,3$ & Low \\
\hline
\end{tabular}

\section{Result}

The research data set can be accessed on osf.io/jmhnk/. The recap of the data on the scores for the lesson plans written by the students in the two cycles are shown in Table 3.

Table 3. Recap of the Results of Calculation of the Scores for the Students' Abilities in Planning a Character Education Integrated Thematic Teaching.

\begin{tabular}{clcccc}
\hline No & \multicolumn{1}{c}{ Dimension } & $\begin{array}{c}\text { Mean in } \\
\text { Cycle I }\end{array}$ & $\begin{array}{c}\text { Categor } \\
\mathbf{y}\end{array}$ & $\begin{array}{c}\text { Mean in } \\
\text { Cycle II }\end{array}$ & Category \\
\hline 1 & $\begin{array}{l}\text { Statement of learning objective and } \\
\text { indicator }\end{array}$ & 54.81 & Poor & 80.47 & Good \\
2 & $\begin{array}{l}\text { Selection and organization of } \\
\text { teaching material }\end{array}$ & 53.61 & Poor & 80.83 & Good \\
3 & $\begin{array}{l}\text { Selection of Learning resources/ } \\
\text { Instructional Media }\end{array}$ & 60.00 & Poor & 80.83 & Good \\
4 & $\begin{array}{l}\text { Model, Method and Instructional } \\
\text { Media }\end{array}$ & 60.00 & Poor & 80.00 & Very \\
5 & $\begin{array}{l}\text { Evaluation of Learning Achievement } \\
6\end{array}$ & 60.00 & Poor & 80.00 & $\begin{array}{l}\text { Good } \\
\text { Toodal Mean }\end{array}$ \\
\hline
\end{tabular}


Table 1 shows that there was a significant increase in the score for the students' lesson plans both as a whole and in each of the five components of the lesson plan design. In the first cycle, the mean for the lesson plan was 57.34 and in the second cycle, it increased to 80.47. Another finding in the first cycle was that the lesson plans of the students had not closely followed the Regulation of the Ministry of Education and Culture No. 22 of 2016, thus at the reflection stage, the team of researchers taught the students about the components of a lesson plan, how to state indicators and objectives, how to write teaching material, including modifications and evaluations. The integration of character values was only stressed at the teaching activity level. This was also less clear in the components of the character values targeted, something that was caused by the fact that the students had not yet understood the description of the 18 characters that had to be integrated into the lesson.

The recap of the ability to teach a character value integrated thematic lesson is summed up in Table 4 below.

Table 4. Recap of the Result of the Calculation of the Scores for the Students' Ability in Teaching a Character Education Integrated Thematic Lesson.

\begin{tabular}{clcccc}
\hline No. & \multicolumn{1}{c}{ Dimension } & $\begin{array}{c}\text { Mean in } \\
\text { Cycle I }\end{array}$ & Category & $\begin{array}{c}\text { Mean in Cycle } \\
\text { II }\end{array}$ & Category \\
\hline 1 & Pre-activity & 80.00 & Good & 88.89 & Good \\
2 & Opening the lesson & 60.00 & Poor & 100 & Very Good \\
3 & Whilst Activity & 70.56 & Fairly Good & 86.17 & Good \\
4 & Closure & 73.33 & Fairly Good & 85.56 & Good \\
5 & Total Mean & 70.96 & Fairly Good & 87.06 & Good \\
\hline
\end{tabular}

Table 2 shows that there was a significant increase in the score for the students' ability to teach from 70.96 in the first cycle to 87.06 in the second cycle. Another finding for the first cycle was that the students' ability to teach was good enough, but the character values that should have been targeted to be developed through the lesson plan components had not been observed. The students tended to develop the characters by making the students accustomed to them and showing examples.

The results for testing the hypothesis using the sign test is summarized in Table 5 below.

Table 5. Recapitulation of Hypothesis Testing Using Sign Test

\begin{tabular}{lcc}
\hline \multicolumn{1}{c}{ Hypothesis } & Asymp. Sig. (2-tailed) & Decision \\
\hline The first hypothesis & $0.000<0.05$ & H0 is rejected \\
\hline Second hypothesis & $0.000<0.05$ & H0 is rejected \\
\hline
\end{tabular}

The first hypothesis testing shows that there is a rejection $\mathrm{HO}$ means that there are significant differences in the ability of students to design integrated thematic learning character values from cycle I to cycle II. Likewise, the testing of the second hypothesis is H0 rejection, meaning that there is a significant difference in the ability of students to carry out integrated thematic learning character values from cycle I to cycle II. Furthermore, testing the effectiveness of lesson study for the ability to design learning obtained a score of 0.54 in the average category, while testing the effectiveness of lesson study for the ability to implement integrated thematic learning character scores obtained a score of 0.55 in the average category. 


\section{Discussion}

The result shows a significant increase in pedagogic competence attained by the students in integrating character values into the thematic lesson. This increase is a positive effect on the implementation of lesson study. Lesson study is effective in enhancing the students' pedagogic competence, especially in designing and implementing a character value integrated thematic teaching. This finding was supported [3] who found in their study that lesson study can increase the teachers' ability in writing a lesson plan and implementing it in each cycle. Thus, from the study, it can be stated that lesson study can develop students' ability in designing a character value integrated thematic teaching. The teacher can do some corrections based on the inputs from the teacher observers who directly followed the teaching process from the preparation stage to the end of the teaching. Through lesson study, the target and the correction from the observers can be followed up by the model teacher in the next teaching session [6]

The development of lesson study is done and based on the result of "sharing" of professional knowledge based on the practice and the result of teaching implemented by the teachers and academicians. Hence, it is very natural that lesson study is able to improve a teacher's knowledge in teaching. Lesson study is an effective way to develop the teaching skills, knowledge, and self-confidence of a teacher [3] This is supported [2] who state that lesson study is able to develop pedagogical knowledge, which means that a teacher can acquire knowledge from other teachers. Lesson study is able to place a teacher as a researcher in teaching, meaning that lesson study is a pedagogic investigation done systematically and is done by individuals in a group with the main objective of improving the quality of teaching [7].

This finding supports several similar studies which found that lesson study was effective in developing teacher competencies [12]. Lesson study consists of the "plan" and "do and see" stages and is done by teachers collaboratively [4]. In lesson study, teachers collaborate in selecting topics and planning the lesson. Then, one teacher does the teaching and the others observe the students in the classroom and discuss the results of the [3] This, in reality, has produced a very positive sociological effect. Collegiality among teachers can be developed well. Hence, through a series of activities, lesson study develops an academic atmosphere that is conducive for the creation of mutual learning. In principle, all people involved in lesson study have to give a lesson learned so that lesson study is potential in developing a learning community.

\section{References}

[1] Lickona, T.: The teacher's role in character education. Vol 179, No. 2, pp 63-80. Journal of education. (1997)

[2] Peraturan Menteri Pendidikan dan Kebudayaan Nomor 20. Jakarta: Kemendikbud. (2003)

[3] Agboola, A., \& Tsai, K. C. Bring Character Education into Classroom.. Vol 1, No. 2, pp 163-170. European journal of educational research. (2012).

[4] Milliren, A., \& Messer, M. H.. Invitations to character. Vol 15, pp. 19-31. Journal of Invitational Theory \& Practice. (2009)

[5] Peraturan Menteri Pendidikan dan Kebudayaan Nomor 57. Jakarta: Kemendikbud. (2014)

[6] Hadi, R. The Integration of Character Values in the Teaching of Economics: A Case of Selected High Schools in Banjarmasin. Vol. 8, No. 7. International Education Studies. (2015)

[7] Ministry of Education. Panduan Pelaksanaan Pendidikan Karakter. Jakarta: Puskur-Balitbang Kemdiknas. (2011). 
[8] Japa, I G. N. \& Diputra, K. S. Improving Teachers' Ability in integrating Character education into Mathematics Subject Matter through Lesson Study in Group V Sukasada Sub-District. International Conference on Lesson Study. Malang: Universitas Muhammadiyah Malang. (2016)

[9] Diputra, K. S. \& Japa, I G. N. Analisis Kemampuan Guru Melaksanakan Pembelajaran Tematik Terintegrasi Pendidikan Karakter. Vol. 2, No. 2, pp. 138-143. International Journal of Elementary. (2018)

[10] Dudley, P. Lesson study: A handbook. Retrieved August 11, 2018. http://disde.minedu.gob.pe/handle/123456789/5017. (2014)

[11] Alvine, A., Judson, TW., Schein, M. \& Yoshida, T.. What Graduate Students (and the rest of us) can Learn from Lesson Study. Vol. 55, No. 3. College Teach. (2007)

[12] Diputra, K.S. \& Tristiantari, N. K. D. Mengembangkan Profesionalisme Guru-Guru Ipa Smp N 1 Singaraja Melalui Pendampingan Lesson Study. Vol. 5, No. 2. Widya Laksana. (2016)

[13] Cerbin, W. \& Kopp, B. Lesson Study as a Model for Building Pedagogical Konowledge and Improving Teaching. Vol.18, No. 3. International Journal of Teaching and Learning in Higher Education. (2006).

[14] Meltzer, D.E. The Relationship Between Matematics Preparation and Conceptual Learning Gains in physicn: A possible " hidden variable" in diagnostic pretest score.Vol. 70. No 12, pp. 1259 - 1268. American Journal of Physics. (2002).

[15] Diputra, K.S. \& Tristiantari, N. K. D. Mengembangkan Profesionalisme Guru-Guru Ipa Smp N 1 Singaraja Melalui Pendampingan Lesson Study. Vol. 5, No. 2. Widya Laksana. (2016)

[16] Sutadji, E., Ibrohim, I., Sutama, W., \& Askury, A. Kefektifan Pembelajaran Bermakna melalui Lesson Study di Sekolah Dasar. Vol 22, No. 1, pp. 033-038. Jurnal Pendidikan dan Pembelajaran. (2016)

[17] Cajkler, W., \& Wood, P. Adapting 'lesson study'to investigate classroom pedagogy in initial teacher education: what student-teachers think. Vol 46, No. 1, pp. 1-18. Cambridge Journal of Education. (2016)

[18] Cerbin, W. \& Kopp, B. Lesson Study as a Model for Building Pedagogical Konowledge and Improving Teaching. Vol.18, No. 3. International Journal of Teaching and Learning in Higher Education. (2006).

[19] Tsui, A. B., \& Law, D. Y. Learning as boundary-crossing in school-university partnership. Vol. 23, No. 8, pp. 1289-1301. Teaching and teacher education. (2007)

[20] Coenders, F., \& Verhoef, N. Lesson Study: professional development (PD) for beginning and experienced teachers. DOI: 10.1080/19415257.2018.1430050. Professional development in education. (2018)

[21] Garfield, J. Exploring the Impact of Lesson Study on Developing Eff ec-tive Statistics Curriculum. (2006)

[22] Lewis, C.C. Lesson Study: A Handbook of TeacherLed Instructional-Change. Philadelpia, PA: Research for Better Schools. Inc. (2002)

[23] Saito, E. Changing lessons, changing learning: Case study of piloting activities under IMSTEP. Prosiding Seminar Nasional MIPA dan Pembelajarannya \& Exchange Experience of IMSTEP. (2005).

[24] Lewis, C., Perry, R., \& Murata, A. How should research contribute to instructional improvement? The case of lesson study. Vol 35, No 3, pp. 3-14. Educational researcher (2006).

[25] Isoda, M., et al. Japanese Lesson Study in mathematics: its impact, diversity and potential for educational improvement. Singapore: World Scientifi Publishing Co., Pte. Ltd. (2007).

[26] Stepanek, J., Appel, G., Leong, M. T., \& Mitchell, M. Leading Lesson Study: a practical guide for teachers and facilitators. Thusand Oaks, CA: Corwin Press. (2007) 